\title{
The Management of Kutai National Park Through the Multi Stakeholder Partnership
}

\author{
Humphrey Wangke \\ School of Environmental Sciences, Universitas Indonesia \\ Jakarta, Indonesia \\ Email: dhanny_2000@yahoo.com
}

\begin{abstract}
The illegal logging and the encroachment in the Kutai National Park is not only have impacts on the loss of biodiversity of flora and fauna but also cause the ecological losses. The governance of partnership managed by the Kutai National Park Management through the establishment of Mitra Kutai has not succeed in reducing the threat of forest destruction in Kutai National Park. By do not involving the stakeholders in the management of Kutai National Park have caused the failure of the partnership. In partnership, Kutai National Park Authority and local communities should become key actors in management, assisted and supported by district governments, corporations, and NGOs.Through the qualitative method, the research found an idea to renewing the form of partnership to managing the Kutai National Park by involving more stakeholders in the partnership that will be formed formally. The engagement of multi stakeholder in this matter expected to save the Kutai
\end{abstract}

\section{INTRODUCTION}

The collaborative approach is essential in the management of the conservation area because it requires not only the local community involvement but also requires the capacity of the conservation's expertise, companies and the government [1]. The involvement of various parties cannot be separated from the necessity to increase the local communnity's capacity in conserving the biodiversity of the conservation area. One thing that also essential to be noticed in this collaborative conservation effort are the equality and justice principle among the
National Park's forest that have rich biodiversity which would be useful in order to achieve sustainable development post 2015 such as poverty reduction, the availability of employment, nutrition and clean drinking water. It is believed that this partnership will not only enhance the people's sense of belonging to the park but also deal with the problem of poor law enforcement and the Indonesian government's lack of contributions in the conservation of the park. The efforts to find the right solutions to address the global environmental issues such as loss of biodiversity, the illegal logging, and the natural disasters are now its time to be implemented in Kutai National Park.

Keywords-- Multistakeholder Partnership; Kutai National Park, Biodiversity; Illegal Logging; Governance; Collaborative.

parties in planning, implementation and evaluation. Therefore, the collaborative management is an effort to give positive impact on the welfare of local community living in the conservation area.

In the Regulation of the Minister of Forestry (Permenhut) No. 19 Year 2004, the meaning of the collaborative management is the implementation of an activity or handling a problem in order to improve the effectiveness of the management of the area collectively and synergistically by the parties based on the mutual understanding and consensus. The collaborative management is required in order to address 
the protracted issues on a conservation area such as a national park. Mostly the conservation areas in Indonesia are under pressure due to three major threats, as follow claims and occupations by local community, the industrial encroachment and the competency conflicts between the central and local governments over the natural resources [2]. This conditions also happened on the management of conservation areas in Kutai National Park [3].

The occupation by the local community becomes inevitable because of very high dependant on land and forest products in Kutai National Park (KNP), which have been done illegally. One of the driving factors for the high level of dependant on Kutai National Park and and forest products is because the majority of local community are poorly educated, so that the variety of work that can be done is also very limited. The local community in Kutai National Park only understand cultivating and farming. The economic condition of local communities lived under the poverty line, which threathning the forests and biodiversity in Kutai National Park.

Until the 1970's local community collect timber from Kutai National Park's forest areas in limited numbers. However, entering the 1970's when the state began massively exploiting the forests around Kutai National Park, known as the "banjir kap" means transporting timber through the river, local communities began to exploit the situation by taking large quantities of timber from Kutai National Park's illegally. Being concerned that Kutai National Park would be more damaged if the illegal logging are lefted, a Forest Protection and Nature Conservation officer at that time, Mr. Saleh Juta directed which land in Kutai National Park could be worked on by the community. This mislead habit carried on even though the Kutai Wildlife Sanctuary changed its name to Kutai National Park in 1995.
The conflict between Kutai National Park Authority and the East Kutai District Government occurred because of the district government often felt burdened by the national park existence in its territory [2]. The lack of understanding from local communities and district governments on the importance of the forest conservation for the future of human beings become the obstacle on the sustainable management of Kutai National Park. The errors on the forest utilization occur in various forms such as neglecting the egulations, apply corruption's practice, abuse of power, illegal logging including trading the wild forest's products. Another error mistake is also in the form of illegal forest conversion for other utilization commonly known as deforestation or activities that resulting forest destruction or known as forest degradation.

In order to overcome the limitations on the management of national park, one of the policy carried on by the government is through partnership, which is through the Minister of Forestry Regulation No.P.19/Menhut-II/2004 in regard to the Collaboration of Nature Conservation Area Management (Kawasan Suaka Alam) and Nature Conservation Area (Kawasan Perlindungan Alam). Through the collaboration, the management of Kutai National Park is not solely carried out by the Kutai National Park's Management as an institution that have been given management's mandated but by involving stakeholders that have concerns to Kutai National Park in order to achieve the management objectives. The developed idea in order to optimize the management of Kutai National Park is by establishing partnerships with the companies around Kutai National Park which is incorporated in Mitra Kutai National Park.

However, the overall partnership between the Kutai National Park Authority and the Mitra Kutai National Park appears 
not yet able to improve the management of Kutai National Park. This can be seen from the increasing number of forest destruction in Kutai National Park. According to data from the Kutai National Park Authority, in 2009 the forests's damages in Kutai National Park has reached the number 20\% from the total area with the range of damage area reached 1,125.1 hectares/year. The increasing number of forest degradation is caused by the rampant of illegal logging and the encroachment activities.

Deforestation and forest degradation ultimately have a negative impact on livelihoods and community welfare, therefore, compliance with the law and good governance needs to be taken seriously by all stakeholders in Kutai National Park. The frail of community compliance with forestry matters and governance arrangements must be addressed through a mutual understanding of the sustainable forest management. The compliance with the law and forest good governance are essential for country and communities that its livelihoods depend on forests.

With this kind of background, this paper will analyze how the management of Kutai National Park through the multi stakeholder partnership should be done so the utilization can be sustainable?

\section{METHOD}

This research using qualitative approach by taking location in Kutai National Park, East Kutai Regency, East Kalimantan Province. The type of data that used is the primary data obtained through interviews and field observations for two months period from December 2014 until January 2015. The informants in this research were made up of government officials, NGOs, companies and local communities. The data collected is related to the problem of managing Kutai National Park, law enforcement, and multistakeholder partnerships. While the secondary data obtained through literature and document studies. The data that obtained were analyzed using qualitative data analysis technique that describing a problem based on the facts.

The determination of the informant research was conduct intendedly and partially through snowball sampling technique that following the informant's previous information in order to determine the next informant [4, 5]. The research involved 60 informants from the superstructure and infrastructure. ${ }^{1}$ The key informants of this research are Head of Kutai National Park, South Sangatta Subdistrict and Teluk Pandan Subdistrict, the Head of Village in both subdistricts. The other informants are local communities who live inside the Kutai National Park.

Validation or the validity testing of data conduct by triangulation of sources and methods. The triangulation of the source is conduct by checking the data to other data sources. The other triangulation method is conduct by interview, followed through by the checking with observation, and documentation [4].

\section{RESULT}

A study conducted by [6], state that the conservation areas are still urgently needed due to several considerations: first, most of national parks in the world adequately are not large enough to sustain rare species populations. Many protected areas in the world are smaller than 10,000 hectares 143 or approximatelyt $80 \%$ of the total protected

\footnotetext{
1 The Suprastructures circle are government officials consist of Minister of Forestry, District Government, Environment Agency, Forestry Agency, TNK, Kodim 0808 Sangatta, Sangatta District Police, Sangatta State Attorney, Sangatta District Court, Head of Sub-District and Head of Village. While the infrastructure is a local community.
} 
areas in the world are in the IUCN I-VI category. Smaller parks own significant local interest, but the research results show that only 10,000 ha of parks own the potential to slowing down the long-term species loss. Second, many endemic sites with high species richness have no legal protection, and the pressure of the land conversion, especially for agriculture, are increases.

In line with the statement of [6], the formation of Kutai National Park are inseparable from the characteristics of the forest area, which are: 1 . The wide of the area nearly 200.000 hectares, 2. Having unique and particular characteristic natural resources of flora and fauna, ecosystems and natural phenomenon are still intact, 3. One or several ecosystems inside the core zone there are materially have not changed due to the human exploitation and occupation, 4. Kutai National Park is still possible to be developed as a natural tourist attraction for the public with the purpose of recreation, education and cultural. The above mentioned 4 features of Kutai National Park are met the requirements of the International Union for Conservation of Nature (IUCN) for the establishment of a national park. Even so the Kutai National Park has other advantages which is located in the lowlands and the widening shape along the equator lines with range from the coast of the Strait of Makasar toward the west approximately 60 kilometers. Through the establishment of Kutai National Park, the protection and the preservation of types of ecosystems, flora and fauna species inside the national park can be conduct in a sustainable manner so that the utilization of the welfare of the local community must be conducted in a controlled manner.

Although the conservation areas are still needed but the effectiveness of national park management is still questionable by many parties [7], including in Kutai National Park
[3]. Kutai National Park is one of the conservation areas that faced a very complex problem since its formation in 1995. The Kutai National Park authority is established along with the establishment of Kutai National Park inherits a very complicated issue that potentially destroys the national park.

From the field's observation the biggest problem inheritance faced by Kutai National Park are illegal logging, conversion of land, and land ownership demands by the local communities. The presence of the local communities in the Kutai National Park area that occurred prior to the establishment of Kutai National Park becaming the emerging of the problem. The management of Kutai National Park became more complicated when in 1997, the formed East Kutai Regency did not support the Kutai National Park conservation policy by the central government. This condition encouraged the arise of conflicts of interest involving Kutai National Park Authority as the manager with the local communities and the district government of East Kutai.

The development of Kutai National Park is not only obstracted by the local communities and the East Kutai district government that do not support the conservation, but also because of its own less strategic position. The Kutai National Park area is surrounded by the centers of economic and urban growth resulting from the policy of regional expansion of Bontang and East Kutai Adminstrative cities, also surrounded by the natural resources extraction companies such as oil and gas mining, coal mining and forestry companies such as Forest Concession Right (Hak Pengusahaan Hutan) and industrial Plantation Forest (Hutan Tanaman Industri).

Based on the RAPPAM (Rapid Assessment and Prioritisation of Protected Area Management) Report on 2005, as quoted by [8], Kutai National Park becomes 
a conservation area with the highest level of threat and pressure among 40 (forty) national parks in Indonesia. Whereas, the Kutai National Park has a very high richness of biodiversity and therefore it has a very crucial role for the achievement of various goals or objectives in the Sustainable Development Goal's such as poverty reduction, the availability of employment, nutrition and clean drinking water. As a lowland tropical rain forest, the Kutai National Park has 1.148 species of identified flora, 80 species of mammals, which 22 species are protected, 368 species of birds and 2.000 orangutans. The Kutai National Park is also a habitat for crocodiles, honey bears, and tree leopards. The illegal logging and the encroachment in the Kutai National Park is not only have impacts on the loss of biodiversity of flora and fauna but also cause the ecological losses.

The ecological value of Kutai National Park is remarkable. One hectare of the forest is estimated to produce 0.6 million oxygen consumed by 1,500 inhabitants per day in order to well breathe of relief. 1 hectare of the forest will dump 2.5 tons of $\mathrm{CO}_{2}$ per year from the atmosphere or 6 kilograms of $\mathrm{CO}_{2}$ per cigarette per year. The forest also in store 900 cubic meters of groundwater and able to lower the temperature between 5-8 degrees Celsius. If the KNP is depleted, its ecological losses are too high [9]. The KNP required to support economic development through its ecological functions, is particularly vulnerable to the exploitation of forest resources along with the increasing need for the resources to improve the economic growth of local communities and local governments.

\section{DISCUSSION}

In carry out the management of Kutai National Park, the Kutai National Park Authority has established which is known as
Mitra Kutai, a collaboration between Kutai National Park Authority and 9 (nine) extraction companies located around the KNP area. All of 9 (nine) mining companies are as follow PT Pertamina, PT Badak NGL (PT BNGL), PT Surya Hutani Jaya (PT SHJ), and PT Kaltim Prima Coal (PT KPC), PT Indominco Mandiri (PT IM), PT Pupuk Kaltim (PT PKT), PT Kaltim Parna Industri (PT KPI), PT. Kaltim Methanol Industri (PT KMI) and PT Pama Persada Nusantara (PT PAMA). The establishment of the cooperation is intended to assist the Kutai National Park Authotity in the management of the Kutai National Park.

However, in its implementation, the bipartite collaboration between the Kutai National Park Authority and Mitra Kutai has not been able to improve the performance of Kutai National Park management. The indication that can be used here is the high level of illegal logging and land function conversion. According to Saparudin from the NGO Bina Kelola Lingkungan (Bikal), the failure of the collaboration is due to the Mitra Kutai only acts as financial contributors but not involve in the management (Interview in Bontang dated $23^{\text {th }}$ of December, 2014). Meanwhile [3] mentioned that, the members of Mitra Kutai have experienced the saturation due the programs activity are not conduct continuously and not intended to overcome the basic problems in Kutai National Park.

However, considering the real conditions in the field, the source of the problem lies in the un-involvement of the local communities in the management of the Kutai National Park. Similar with local communities, practically there are no NGOs, both domestic and abroad are involved in the management of Kutai National Park. As a result, the ability of the Kutai National Park to communicate the indirect values of the conservation activities to the local communities is obstracted. For an example, 
about the the losses arising from the illegal logging or land clearing within the area, losses incurred if the animals die, and losses from water pollution in the upstream area or if the water storage capacity in the upstream area decreases which cause the water flow decreases drastically. As revealed by the informants, the Kutai National Park Authority never tells residents which areas they allow to use, whilst, the borders of the Kutai National Park in the local communities are seem unclear.

The lack of communication cause conflict between the local communities and the Kutai National Park authority about the status of the area and the possible activities conduct in the area. Poor communication quality also devitalise the inter-agency coordination within and around the Kutai National Park as they work independently on the basis of their respective agency plans without any coordination. The miscommunication occurs because the Kutai National Park Authority practically works alone in managing the Kutai National Park. The Mitra Kutai that formed, only function as a financial contributions, not involved in management. Similar with the local communities. they have become marginalized within the Kutai National Park area.

In order to reduce the communication gap, the research findings that the partnership that involving only two parties will be difficult to implement optimally. Although the companies incorporated in Mitra Kutai provide the financial contributions to the management of Kutai National Park but the condition of Kutai National Park is not getting better. More widespread communication and dissemination of and effective information will increase the awareness and the commitment of various stakeholders in order to maintain the integrity and the sustainability of the ecosystems within Kutai
National Park areas. For that purposed the partnership should embrace all concerned parties for the future of Kutai National Park.

The involvement of the local communities is essential given the longstanding local community in and around the area before it is established. Therefore, by eliminating local communities in the management of the conservation areas is unlikely impossible, considering their interaction, understanding and dependencyce on the region are already too high. The local community should be considered an asset which its existence can support the realization of the conservation area management. It is time for the state to build collaboration among the stakeholders in order to manage the conservation area in a sustainable and prosperous way for the local community.

Based on observation and interview, the management of Kutai National Park is still not optimal yet. Although the management paradigm has shifted from a safeguard approach to a collaborative approach in which emphasize on the participation of the parties through the partnership, the existing partnership is unable to cope with the escalation of the forest degradation. According to [10], the public-private partnerships requires the collaboration in order to be functioning, however, the goal is only to achieve coordination and not to achieve the consensus decision-making. Therefore, the partnership in the national park management through should involve the stakeholders in the decision-making, including in planning, implementation and the assessment.

To be able to implement the planning, implementation, evaluation program, then the partnership should be formal. Each stakeholder involved is a representative of a stakeholder who understands the importance of a conservation forest such as Kutai National Park. In partnership, Kutai 
National Park Authority and local communities become key actors in management, assisted and supported by district governments, corporations, and NGOs. There are several objects that require collective agreements for jointly designed partnerships among stakeholders to be effective, such as national park governance, institutional establishment, land tenure, land and incentive restrictions, road access diversion, land boundaries, law enforcement, and sustainability of Kutai National Park. In accordance with the theory of sustainable development, the object of arrangement will focus on economic, social and ecological aspects.

The failure of Mitra Kutai in managing the Kutai National Park provides an important lesson that National Park must have a new approach that can be applied by the Authority, the local community, and any other stakeholders who have concerns with Kutai National Park as a managed object. Until now, the paradigm that emerged in the community is the function of the Authority which is appear not more than as a object's guard, which will catch the local community if they tried to use Kutai National Park without permission from the Kutai National Park Authority. Kutai National Park Authority paradigm as a "watchdog" is already developed and attach to the people who live and residence in the area of Kutai National Park. Even the local governments seem to be unwilling to compromise with the Kutai National Park Authority related to the condition of the local society in the region. Therefore, a new approach is required to address all the gaps that arise in the management of Kutai National Park.

In principle, Kutai National Park as a Nature Conservation Area shall be supported and conserved by the stakeholders considering it has the economic and ecological benefits. This is certainly related to the biodiversity contained in it, especially the flora and fauna species that endangered or vulnerable and shall be protected (Endangered Species of Wild Fauna and Flora) such as the Ulin Tree and the Orang Utan. The existence of Kutai National Park is very pathetic, it is marked by logging and burning, the increasing number of people live therein, and many parties that threaten the existence of Kutai National Park by reducing the wide range of Kutai National Park's area.

The national park management paradigm which has been conduct all this time must be changed. The top-down approach practiced by Kutai National Park Authority have failed in order to bring forward the local community's initiatives and participation, and also not accommodative to the needs of the local communities. The top-down approach in fact do not emphasize the local communities' capacity and the other stakeholders involved in environmental management, so there is no sense of ownership among those who involved. The NGOs were also not found in Kutai National Park.

Given the real conditions on the field, the dominant role of the government should be reduced because it has created difficulties for the development of sustainable management of the conservation areas. The stakeholders' interest in Kutai National Park, such as local communities and local governments, the NGOs and the intellectuals now it is time to involved in it, in order to accommodate the actual interests and conditions on the field, in accordance with the capacity of the stakeholders involved in it.

In line with the development of the control and the management practices of national park, the function of Kutai National Park Authority in several other national parks is already running in a new paradigm. In some national parks, such as Bromo Tengger Semeru (BTS) and Alas Purwo, 
which the Authority formerly acting as a "watchdog", nowadays become consultants which provide inputs in the form of thoughts, ideas for the improvement of the exisxting system and give recommendation a solution of problem solving together with the government and the local communities.

In order to carry out this role, the authority has a nature as a characteristics catalyzer, providing the constructive suggestions that applicable for the progress of the society, however remain independent in carry out the operational activities in safeguarding the national park. In this case, the authority can be a strategic business partner for the community, the company and the government, so the awareness of the community will arise by itself in regard to the importance of the national park for them as well as bring a new job for them without destroying the forest.

The efforts to find the right solutions to address the global environmental issues such as loss of biodiversity, the illegal logging, and the natural disasters are now its time to be implemented in Kutai National Park. An innovative approach is required in order to resolve the environmental issues caused by the human greed which stand against the governance model whom controlled by the state. The multi stakeholders partnership between the government agencies, business actors, the NGOs and the local communities it should be done in order to increase the possibility of creating a safe space for human beings.

The collaborative partnership governance are expected to be more efficient, effective and inclusive. A bottomup multi stakeholder partnership is the answer for maintaining and managing sustainable conservation areas. This multistakeholder partnership has played an important key role in order to implementing the sustainable development objectives since the World Conference on Sustainable
Development on 2002 in Johannesburg. Since then, the partnership approach has been used to resolve problems related to the natural resources such as health, the water governance and the climate change.

Referring to [1], in a partnership-based collaboration the parties involved are voluntarily will share the functions, rights and the responsibilities for conservation of the protected areas and associated resources [11]. On theory are explained the governance of the partnership should be conduct formally by involving the infrastructure's party or the suprastrucuture which have the same purpose or objectives [12]. Their involvement should be conduct start from planning, implementation and to evaluation without neglecting the equality in decision making. The local communities who live around the Kutai National Park should be the key person which expected to participate and give benefits from the resources management. The partnership on the conservation emphasized in the development of wildlife-based tourism, so the communities receive the benefits without damaging the Kutai National Park.

From the field research shows that whether the Kutai National Park authority, the local communities, the district governments, the corporations and the NGOs strongly desire to work together in order to solve problems in Kutai National Park. This kind of initiative has never been done before by Kutai National Park authority. The existence of this strong desire is a step forward because the assumption of the equality in cooperation partnership has never happened. Moreover, the government through the Ministry of Forestry is aware the importance of th ecommunity involvement in forestry development, especially related to the prevention of the illegal logging and the forest encroachment since the end of the New Order's era [13]. 
Through the establishment of the collaborative relationship among the stakeholders will facilitate the emerge of voluntary compliance. However, the arrangements should be made clear and easy to understand also related to the territory borders which can be utilize by local communities should be clearly defined and mutually agreed on. The trained rangers with complete and highly motivated are essential to the national park's sustainability, however the adequate governance must ensure that penalties are applied and consistently enforced.

\section{CONCLUSION}

The multistakeholders partnership which involving the stakeholders in the Kutai National Park are become the solution to save the Kutai National Park from the destruction. The involvement of the stakeholders the Kutai National Park's management, such as Kutai National Park Authority, NGOs, local communities, and companies, start from the planning until the evaluation will increase their sense of belonging and responsibility to save the Kutai National Park forest. Through the formal consent agreements, the stakeholders will share duties and responsibilities in accordance with their capacity. The involvement of companies which is previously incorporated in Mitra Kutai is not only a financial contributor but also involve in the management of Kutai National Park.

\section{REFERENCE}

[1] Borrini-Feyerabend, G. (1996) CollaborativeManagement of Protected Areas: Tailoring the Approach to the Context. Gland (Switzerland): Issues in Social Policy, IUCN.Andrade, G. S. M., and J. R. Rhodes. 2012. Protected areas and local communities: an inevitablepartnership toward successful conservation strategies? Ecology and Society 17(4): 14.
[2] Moeliono, M. and Purwanto, E. 2008. A Park in Crisis: Local Governance and National Policy. Paper presented at "Governing shared resources: connecting local experience to global challenges" Biennial Conference of the International Association for the Study of The Commons, Cheltenham, England, July 14-18 2008.

[3] Falah, Faiqotul. (2013). Study on Collaborative Management Effectiveness of Kutai National Park (Kajian Efektivitas Pengelolaan Kolaboratif Taman Nasional Kutai), Jurnal Analisis Kebijakan Kehutanan), Vol. 10 No. 1, pp. $37-57$.

[4] Sugiyono. (2010). Memahami Penelitian Kualitatif (Understanding Qualitative Research), Alfabeta, Bandung

[5] Irawan, Prasetya. (2006). Penelitian Kualitatif dan Kuantitatif Untuk Ilmu-ilmu Sosial (Qualitative and Quantitative Research for Social Science). Departemen Ilmu Administrasi FISIP UI, Depok.

[6] Naughton-Treves, L., Holland, M.B., Brandon, K. (2005). The Role Of Protected Areas in Conserving Biodiversity and Sustaining Local Livelihoods. Аnnu. Rev. Environ. Resour, 30:219-52. Naughton-Treves, L., Holland, M.B., Brandon, K. (2005). The Role Of Protected Areas in Conserving Biodiversity and Sustaining Local Livelihoods. Annu. Rev. Environ. Resour, 30:219-52.

[7] Hayes, Tanya M. (2006). Parks, People, and Forest Protection: An Institutional Assessment of the Effectiveness of Protected Areas, World Development Vol. 34, No. 12, pp. 2064-2075.

[8] Supriatna, J. (2008). Melestarikan Alam Indonesia. Jakarta: Yayasan Obor Indonesia.

[9] Kutai National Park. (2013). The lungs of the increasingly hollow world (Paru-paru dunia yang Berlubang), Kompas.com, 23 April, accessed July 30, 2017.

[10] Ansell and Gash, Collaborative Governance in Theory and Practice, Journal of Public Administration Research and Theory, 2007, ppl. 544.

[11] Nshimbi, Muleba and, Vinya, Royd. Impacts of Public-Private Partnership on Local Livelihoods and Natural Resource Dynamics: Perceptions from Eastern Zambia, Resources 2014, 3, pp. 471-487.

[12] Brinkerhoff, Derick W., and Brinkerhoff, Jennifer M. (2011). Public-Provate Partnerships: Perspectives on Purposes, Publicness, and Good Governance, Public Administration and Development, 3, pp. 2-11. 
[13] Minister of Forestry Regulation No. P.39/Menhut-II/2013 on empowerment of local communities through partnership. (Peraturan Menteri Kehutanan nomor P.39/Menhut-II/2013 tentang pemberdayaan masyarakat setempat melalui kemitraan). 